\title{
Swot Analysis in the Planning of Software Product Marketing Strategy to Cope With Creative Economic Era in Indonesia (A Case Study at Pt. Patt in Malang)
}

\author{
Amugya Indra G. A, Budi Eko Soetjipto \\ Study Program of Master of Management, Universitas Negeri Malang
}

\begin{abstract}
The objective of this research was to analyze a variety of marketing strategies such as Partner Relationship Management, Product Development, and Market Penetration, as well as its usage to cope with Creative Economic Era at Technology Information (TI)-based companies. Research type was qualitative descriptive. Result of research with SWOT method showed that that 1) IFAS rate was 1.48 and 2) EFAS rate counted for 0.45. SWOT Diagram had positioned marketing strategies into Quadrant II, meaning that the strategy was diversification. Diversification was making new product for new segment. Result of interview discovered that companies with diversification strategy were those applying Partner Relationship Management, Product Development, and Market Penetration. Pursuant to the result of SWOT Analysis, therefore, Partner Relationship Management, Product Development, and Market Penetration were proper to be used as marketing strategies for software product at PT. PATT to cope with Creative Economic Era.
\end{abstract}

Keywords: SWOT Analysis, Marketing Strategy, Diversification, Creative Economy, Partner Relationship Management, Product Development, Market Penetration

\section{Introduction}

Information technology can help human to increase the efficiency of work. The science of information technology has developed many branches, including among other information engineering, computer science, and information system. Many programming practitioners also have produced various application programs, such as online web, management system, games development, and others. By improving their competence in making application program, programmers take a lot of profits from various clients and keep programming as their job. Programmers may handle certain project, or even be hired as a supplier for certain company. It may be not a simple work, and therefore, programmers usually hire other programmers and built a team. It is why programming practitioners use such job as their entrepreneurship and call themselves as the entrepreneur.

PT. PATT. Is a company located in Malang City, East Java Province, Indonesia. It is a company with information technology (IT) and aimed to use technology as a solution to various problems, including how to improve efficiency of managerial performance, advertising, games development, and animation. Therefore, PT. PATT carried a tag-line called "Digital Solution for Smarter Life", meaning that digital technology could be a smart solution to surrounding environmental problems. PT. PATT was initiated as a technology-based enterprise in 2012. Nowadays, PT. PATT focuses on managerial application programs such as SCANS, a sales control application, and HRXpress, a managerial HRD application. The company also expands its products into creative industry segment and it involves the collaboration between technology and art. This interest was taken into account because the world of technology moves very dynamic. Technology advances very quick in term of a year. Therefore, understanding the change of external environment must be an important skill for being a marketer of technology. Innovation may also be needed to help staying competitive on the quality of product and service when it must cope with external environment. It should be the important consideration for the company if it wants to survive amidst strict competitors.

Creative Economic Era in Indonesia is given attention by PT. PATT. This era had invited opportunities to expand marketing segment. There were 16 creative industry sectors, among other including games development, animation, fashion, music, culinary, video, topography and others. Each city in Java and Bali had its own business incubator to exploit resources from creative industry sectors. In Malang City, its business incubator isMalang Creative Fushion known with its 3-C principle, involving Connecting, Collaboration and Commerce. Malang Creative Fushion as business incubator attempted to bridge entrepreneurs and investors with creative industry businesspeople to improve the sale of creative works on market demand. This opportunity must not be separated from technology because it also helped improving the participation of stakeholders into business incubator.SWOT Analysis was a method frequently used in planning a marketing strategy. It contained with four parts, precisely strength, weakness, opportunity, and threat. SWOT analyzed internal and external conditions of the company to ensure whether it influenced product marketing. It was a rationale behind why 
Swot Analysis in the Planning of Software Product Marketing Strategy to Cope With ....

SWOT Analysis was used to analyze software product marketing strategy at PT. PATT when the company must cope with Creative Economic Era.

\section{Problem Formulation}

By taking account research background, the formulated problems are: (1) What SWOT Analysis means for marketing strategy planning? (2) What Marketing Strategy means?(3) What Creative Economic Era means? (4) How SWOT Analysis is applied in the planning of software product marketing strategy to cope with Creative Economic Era in Indonesia? (5) What strategy is compatible to cope with Creative Economic Era?

\section{Research Focus}

1. The description about SWOT Analysis in the planning of software product marketing strategy at PT. PATT to help the company coping with Creative Economic Era in Indonesia.

2. The use of SWOT Analysis in the planning of software product marketing strategy to help the company coping with Creative Economic Era.

3. The alternative of software product marketing strategy used by PT. PATT in Malang.

\section{Research Object}

PT. PATT in Malang moved in software house business. It was found in 2012 and classified as a startup company. It used a simple organization structure, comprising of Director, IT Marketing, IT Developer and Production. Until now, PT. PATT has produced many managerial application programs including HRXpress for HRD management and SCANS for sales monitoring. The company also produces online application web and serves CCTV installation. Table 1 shows the list of product sales from 2013 to 2016.

Table 1: List of Product Sales of PT. PATT from 2013 to 2016

\begin{tabular}{|l|l|l|l|l|l|}
\hline Product Name & Product Type & $\begin{array}{l}\text { Price (in } \\
\text { millions) }\end{array}$ & $\begin{array}{l}\text { Year of } \\
\text { Production }\end{array}$ & Client & Promotion \\
\hline SCANS & Sales Application & 30 & 2015 & PT. Prima Multiusaha & Via Sribulancer.com \\
\hline CCTV Unisma & CCTV & 50 & 2016 & UNISMA & Web, Internal \\
\hline HRXpress & HRM Application & 75 & 2014 & JNE Malang & Web, Internal \\
\hline Server Deployment & Server & 85 & 2016 & PT. RHYS & Internal \\
\hline Server Deployment & Server & 85 & 2016 & Univ. Brawijaya & Internal \\
\hline Printer & Printer Passbook & 125 & 2016 & POLDA JATIM & Internal \\
\hline CCTV Bisturi & CCTV & 6.5 & 2016 & CV. Bisturi Pratama & Internal \\
\hline Lazisnu JATIM & Website & 5 & 2016 & LAZISNU JATIM & Internal \\
\hline CCTV PRIDA & CCTV & 8 & 2016 & DR. Prida & Brochure \\
\hline CCTV Rinda & CCTV & 9 & 2016 & DR. Prida & Brochure \\
\hline CCTV Unisma II & CCTV & 65 & 2016 & UNISMA & Brochure \\
\hline EMT & Web Application & 120 & 2014 & PLN Jatim & Internal \\
\hline SATPAS & Web Application & 100 & 2014 & Karlantas POLRI & Internal \\
\hline SARPPAS & Web Application & 100 & 2013 & SSARPRSAS POLRI & Internal \\
\hline Green Metro & $\begin{array}{l}\text { Web + Mobile } \\
\text { Application }\end{array}$ & 50 & 2014 & Greenmetro car & Internal \\
\hline
\end{tabular}

PT. PATT had sold a lot of products such as HR Application, Sales Application, CCTV, Web Application, Printer Passbook, and Server. HR Application was a managerial application for payroll (salary payment), absence, staff profile and staff leaves. Sales Application was an application to monitor the achievement of sales target. This application can be installed on Android. Web Application was set on website for online usage. Server, CCTV and Printer Passbook were related with infrastructure deployment.

Technology helps us to do something. Its facilitation gives us a value or even added-value, if technology can be combined with science. Therefore, technology may be split into categories. Some of them include managerial application, online web application, 3D hologram, mapping animation, games and others. Concerning with the products, PT. PATT has manufactured its products by focusing on online web application, managerial system application, and server and CCTV installation. In average, company clients are big companies. The marketing involves strategies. Therefore, until now, PT. PATT used online website and some distributors to do the marketing on behalf of the company.

Creative Economic Era in Indonesia

According to Pangestu (2014: vi), Creative Economic had a huge potential to be one of driving sectors that brought the nation to achieve its aspiration being "Indonesia that is self-sufficient, progressive, just, and prosper". It had been settled as the Development Vision of Indonesia Toward 2025. Creative Economic was an economic mobilized by the creativity derived from knowledge and idea developed by human resource in seeking innovative solution for problems. In other words, creativity was a renewal resource, and it will not run out if Indonesian creative human resource can still create something and give additional value in favorable climate. 
Creative Economic not only contributed Indonesia economic, but also implied positive impact on social, cultural and environmental aspects. Through the creative economy, we can foster sustainable and inclusive economy, lifting a positive image and identity of a nation, preserve the culture and the environment, foster the creativity that drives innovation, and increasing social tolerance among all levels of society because of the increasing of cross-cultural understanding. Until 2025, creative economic is expected to be able to realize a competitiveness Indonesia and quality life of society. Pangestu (2014: 17) Based on the development of the concept and definition of the creative economy, then the creative economy can be defined as "creation of value added based on the idea that was born from the creativity of human resources (creative person) and based on the use of science, including cultural heritage and technology." "

The main resource in the creative economy is creativity which is defined as the capacity or ability to produce or create something unique, creating a solution from a problem or do something different from the standard (thinkingoutside the box). Creativity is a factor that drives the birth of innovation by utilizing the existing invention. Innovation is the transformation or implementation of an idea or ideas based on creativity by utilizing the existing inventions to produce a product or process that is better, value-added, and useful. While the invention is creating something that has never existed before and is recognized as a work that has a unique function. Therefore, creativity is very important in encouraging the birth of innovations that efficient and competitive (Pangestu 2014:18).

Creative economy is closely related to the creative industry, but the creative economy has a broader scope than creative industry. Creative economy is an ecosystem that has a relationship of interdependence among the creative value chain; nurturance environment; market and archiving. Creative economy is not only related to the creation of economic value added, but also the creation of value added in the social, cultural and environmental. Therefore, the creative economy beside could improve the competitiveness, it can also improve the quality of life of the Indonesian nation. Creative industry is a part or subsystem from Creative Economy, which consist of corecreative industry, forward and backward linkage creative industry. Core creative industry is a creative industry in which the primarily value added creation is the use of the creativity of creative person. In the process of the creation of value added, core creative industry requiring output from other industries as input. Industry which serve as input for the core creative industry is referred to as backward linkage creative industry. Output from core creative industry also can be input for other industries, which called as forward linkage creative industry. By looking at the linkages between industry groups as core creative industry, backward and forward linkageindustry, then it can be concluded that amongst 15 creative industrial group wereinterconnected although each of industrial group has the different industrial characteristics. Creative industry is a driver of economic value creation in the era of creative economy. In the process of creative value creation, creative industry not only create economic transactions, but also social and cultural transactions. The general process that occurs in the creative value chain is the creation-production-distribution-commercialization, but each group of creative industry have different creative value chain. Based on this insight, the creative industry is defined as "industry which produces an output from the utilization of creativity, skills, and individual talents to create value-added, employment, and improved quality of life"

There are three strategies to improve the competitive and dynamic local creative entrepreneurs: (1) Facilitate the upgrading of skills-knowledge-attitude of creative entrepreneurs with presenting experienced business mentors in national and global level so that could become a competitive and dynamic local creative entrepreneur. (2) Facilitating the collaboration, cooperation and partnerships, and networking among the creative entrepreneurs in the local, national, and global level. (3) Facilitating and developing the business incubators that involves all stakeholders and professionally managed.

Based on the analysis of the above strategies then established the business incubators in several cities in Java to Bali. In the Bali island there was BCIC (Bali Creative Industry Center). InMalang city itself therewas MCF (Malang Creative Fushion). Enshun Jr (2009) business incubator as a formal environment designed to stimulate the growth and development of new and early stage companies by increasing their opportunities for the acquisition of resources which aimed to facilitate the development and commercialization of new products, new technologies and new business models. Similarly, I define business incubation as a social and managerial process aimed to support the development and commercialization of new products, new technologies and new business models. Besides that, According infoDev 2009 in Al - Mubaraki (2012) business incubation program that aims to promote community economic development by supporting companies and their start-ups in business development. These programs offer services to support the establishment and development of new companies / small and medium enterprises. The program also provides incubation with start-up consultation and business planning, consultation in all important areas to business development and growth consultation for and / or access to financing, training and networking. Cantu (2015) incubator maintain start-up evolution'primarily provide network support. Incubator supports a variety of network level, not only at the level of internal (incubators and incubatees), but also the external (local and international), as shown in the cases analyzed. Network incubator improving external network, supporting startup in the innovation of partners selection and the involvement. 
Startup need to choose the right stakeholder with which developing long-term relationships to co-create effective business. Busler (2010) Business incubators contribute to the economy and play an active role in the local economy, regional and national development. Their adaptation supports a diverse economy, commercialization of new technologies, create jobs and build wealth.Malang is one of the cities that participated in driving the Indonesian move towards a creative economy. MCF has a mission to build a culture of creative people, develop the spirit of collaboration and mutual support in building the business and resolve the community issues, creating the network of cross expertise and institutions for the establishment of communication that triggers creativity and innovation, collaborated in building a strategic facility to ensure creative works that can be developed and useful to society, and become information center of creative industry development in Malang city. MCF itself perform Quadroholix synergy pattern amongst the community, academicians, government and employers. MCF also had the principle of connecting, collaboration, and commerce (Malang Creative Fushion team). In Malang city there are a wide variety of creativepreneur sectors that carried by MCF. Accoding to Malang Creative Fushion team, Thereare 16 sectors that found in Malang City: (1) Application \& Game developer, (2) Architecture, (3) Interior Design, (4) Visual Communication Design, (5) Product Design. (6) Fashion, (7)Movie, Animation, and Video, (8), Photography, (9)Kriya/ Craft, (10), Culinary, (11)Music, (12) Publishing, (13) Advertising, (14) Performing Arts, (15) Fine Arts, (16) Television and Radio. Indonesia towards the era of creative economic represents a new era in which the Indonesian government will focus on the creative resources that exist in Indonesia. The creative industry is already emerging for a long enough. This is based on the number of entrepreneurs from various sectors that has already started its business since a few years ago. The actors of the business in the creative industry can be called with creativepreneur.

\section{SWOT Analysis}

According to Rangkuti (2016) SWOT analysis is the identification of the various factors systematically to formulate the corporate strategy. This analysis is based on the logical that can maximize the strength and opportunity, but simultaneously can minimize weakness and threats. The process of strategic decision making is always associated with the development of the mission, goals, strategic and corporate policy. Therefore, strategic planner should analyze the company strategic factors (strength, weaknesses, opportunities, and threats) in conditions that exist today. This is called the analysis of the situation. The most popular models for situation analysis is SWOT analysis. According to Beckeman and Skjoldebrand in Athanasios (2014) this method investigating the macro and micro environmental factors that influence market. In the journal of Emerald Insight with the title is SWOT analysis still fit for purpose? the management tool has been exploring strengths, weakness, opportunities and threats for decade, SWOT can be compared to a photograph, rather than moving images. Perhaps that the greatest weakness lies, SWOT is a snapshot or a state at that time only. Because the environment is constantly changing and new strategies also have an effect on the internal strengths and weaknesses, environmental scanning is required regularly to update the analysis. It is more important to be aware of factors that can influence strategic planning rather than their actual classification. Opportunity which is not be taken may also be a threat. Future research would conduct well to consider focusing on the development of a strategic plan from a SWOT analysis and to ensure that the variables are ordered and weighted to add a focus for decision makers. Therefore according to Hooley and Saunders in Brooksbank (1999) development of successful marketing strategies is basically an optimum searching process of " fit " between the company and the competitive environment in which it operates and not just today's environment, but also that from the future.

\section{Marketing Strategy}

Marketing is an activity of the development of the way of communication, deliver and offer something that has a value to the client, customer, partner and social environment. According to Kotler (2009: 39) the products is merely a tool of consumer problem solver. Marketers not only think about what product will be made, but also the value so that the consumer feel an experience. On one of the marketing process, there is one important thing, which is how to develop a relationship with the customer or so-called customer relationship management. According to Kotler (2009: 46), customer relationship management built through two things, customer value and customer satisfaction. Customer value is the value from a product that can be given to the customer, while customer satisfaction is something perceived by customer from the value of a product. Marketer must be able to create programs for thegood customer relationship management. This is become the consideration to increase the product value in the planning of a marketing strategy. To increase the value by comparing the condition of the company there are some recommended strategies:

\section{a. Partner Relationship Management}

Partner Relationship Management is collaboration with other departments either from within the company and outside the company to provide the best value to the consumer. According to Kotler (2009: 52), to 
make a good customer relationship management needed a good partner relationship management also. This is because the company realize to build the value and a strong customer relationship management cannot be done alone. Partner Relationship Management consist from distributor, retailer, and anyone whose associated with the company (Kotler 2009: 54). According to Mitrega (2012) knowledge about the business partners is very important to the company's distribution, because through the knowledge that it can be more easily reconfigure the portfolio of business partners. In turn, this may be important to develop innovative offers to customer. According to Walter in Wang (2012) the assumption that the supplier will only be successful in the market as they offer "more" value to their customers compared with their competitors. Meanwhile according to Ulaga and Eggert in Wang (2012) empirical study have suggested that the relationship value could originated from the various elements, such as product quality, delivery performance, cost of operation, acquisition, and market timing. According to anthanasios (2014) Success in theMarketdepends on a chain concept of "value added", in which the producers seek to increase the benefits of the product for the customers and build a strong reputation for their business.

\section{b. Product Development}

According to Kotler (2009: 76) Product Development is the strategy for the company growth by offering modified products or new products in the current market segmentation. New Product Development(NPD) is an important strategy to meet the customer demands, increase market share, sales and earnings and competitiveness of the organization (M. Akarte and Sanjaykumar R. Gangurde 2015). According to Cooper, Urban, and Hauser in Estelami and Heather Bergstein (2002) New Product Developmenttraditionally represents diversification efforts of the company in improving the existing products to meet the changing needs of consumers. According to Norman in Gruber, Alexander, and Isabelle (2006) In general, product development can be separated in new product innovations and additions of existing products. What makes competing with market leader is very difficult is the fact that they often apply a combination of enhancements and innovations to secure their positions (Gruber, Alexander, and Isabelle 2006).

\section{c. Market Penetration}

According to Kotler (2009: 74) market penetration is the strategy of the company's growth by increasing sales in existing products to current market segments without changing the product. Changes can be made on advertisement, price, and service. Toor (2014) market segmentation is a marketing strategy to divide the broad market into the subsets of consumers with common needs or priorities and strategies to target them. By identifying similarities, businesses can target different market segments with different marketing strategies. Market segmentation is often used to assess the market potential, identifying the ideal targets of market segments and designing the marketing mix to achieve the targeted segment. Mariscal (2009) as several studies have shown a strong correlation between the dramatic growth in the penetration with pricing strategy. Pricing strategy involves how the prices are determined, distributed and paid among the customers. Minola (2012) The ability and skills possessed by employers also resulted in fairly strong competitive advantageswhich aggressively defended by contrast of the coming of new competitors, also through the practice of predatory prices.

\section{Research Method}

The appropriate method used in this research is qualitative descriptive, namely research that illustrates carefully about specific individuals or groups on the circumstances and symptoms that occur. Beside that also guiding the researchers to explore and or capture the social situation which will be studied thoroughly, broad and deep.In this study, researcher is as a full observer because researcher used a qualitative descriptive method. Researcher observed all the activity in the company for analysis and can be used as the study variables so that forming a pattern and can take the conclusion. The presence of researcher become the key factor in qualitative research because the researcher as a planner, data collectors and reporting actual data from the research results.

This research was conducted at the company of PT. PATT which located in a residential cluster Estate of Abdurrahman Saleh Malang City East Java province Java Island, Indonesia.In this study, researcher obtained the primary data source with the observation of activities in the company and an interview with the General Manager of the company. Secondary data were obtained through field notes, JITC (Jawa Timur Information Technology Center) and MCF (Malang Creative Fusion) as a business incubator in Malang City, and literature books.In this study, researcher used data collection technique through in-depth interviews with the General Manager of PT. PATT. In Semi Structure interview. Interviewers prepare some questions in the form of opinions and company ideas regarding with internal and external conditions of the company. This was conducted in order the interviewer can be more detailed get the information regarding the company's internal conditions, the effect of company external conditions on the internal conditions, and the strategies used so that the company can survive in the competition condition. In addition interviewer also interviewed social conditions 
outside the company. Interviews were conducted with some of the actors in the organizational structure of the business incubator, besides that also conducted to some practitioners of SMEs in the creative industry. This was conducted to observe the company's external social conditions that influence the company's internal condition.

\section{Data Analysis}

The data analysis in this research was SWOT analysis using SWOT Matrix. The aim is to determine whether the strategy of Partner Relationship Management, Product development, and Market Penetration can be used as a marketing strategy in the Technology - based company of PT.PATT.

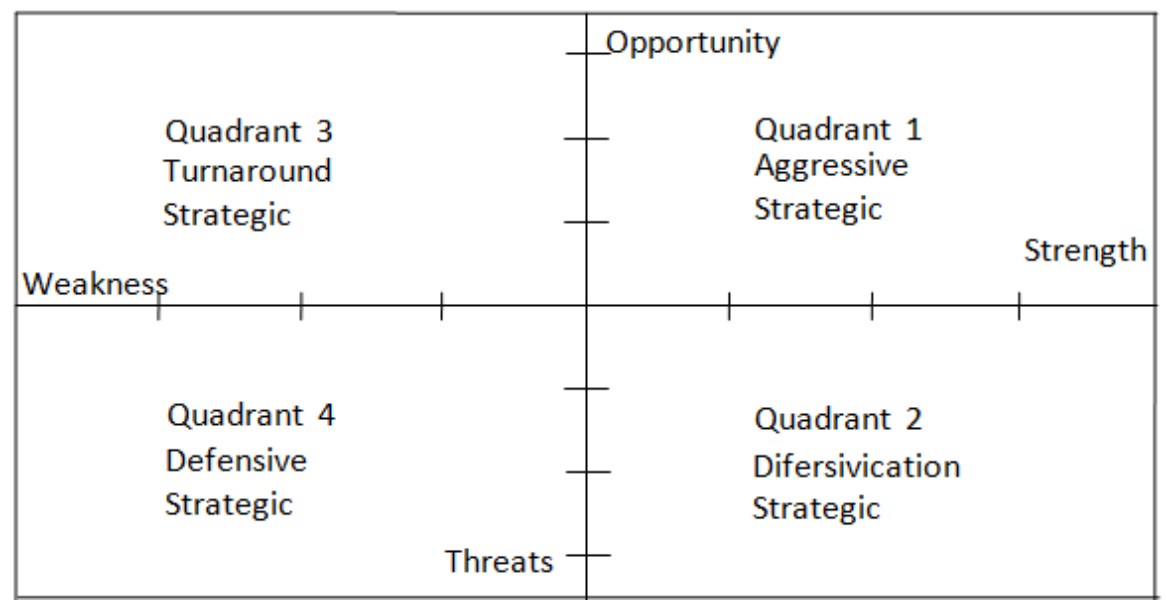

Source :Rangkuti (2016: 20)

Figure 1. Diafram of SWOT Analysis

\section{Matrix of Internal Strategy Factor}

Analysis of the company's internal strategic factors that need to be identified, then created a table of IFAS (Internal Strategic Factors Analysis Summary) arranged to formulate internal factors within the framework of Strength and Weakness of the company.

Table 2: Matrix of IFAS

\begin{tabular}{|l|l|l|l|l|}
\hline \multicolumn{2}{|l|}{ IFAS (External Strategic Factors Analysis Summary) } & \multicolumn{2}{l|}{ Score } \\
\hline No & The Factors of Internal Strategic & Worth & Rating & Score(Worth x Rating) \\
\hline & STRENGTH & & & \\
\hline 1 & The Availability of Online Marketing & 0,1 & 4 & 0,4 \\
\hline 2 & The Existence of Internal Links & 0,3 & 4 & 1,2 \\
\hline 3 & Etc. & $\ldots$ & $\ldots$ & $\ldots$ \\
\hline & Strength Total Score & & & $\ldots$ \\
\hline & & & & \\
\hline & WEAKNESS & & & \\
\hline 1 & Human Resource Development & 0,1 & 3 & 0,3 \\
\hline 2 & Take Time in The Product Segment Expansion & 0,1 & 4 & 0,4 \\
\hline 3 & Etc.. & $\ldots$ & $\ldots$ & $\ldots$ \\
\hline & Weakness Total Score & & & $\ldots$ \\
\hline
\end{tabular}

Source : Adapted from Rangkuti $(2016: 27)$

\section{Matrix of External Strategy Factor}

Analysis of the company's external strategic factors that need to be identified, then created a table of EFAS (External Strategic Factors Analysis Summary) arranged to formulate external factors within the framework of Opportunity and Threats of the company.

Table 3 : Matrix of EFAS

\begin{tabular}{|l|l|l|l|l|}
\hline EFAS (External Strategic Factors Analysis Summary) & \multicolumn{2}{l|}{ Score } & Score(worth x Rating) \\
\hline No & The Factors of External Strategy & Worth & Rating & \\
\hline & OPPORTUNITY & & & \\
\hline 1 & Creative Economy Industry Environment & 0,05 & 3 & 0,15 \\
\hline 2 & Segment Product Development Opportunities & 0,05 & 3 & 0,15 \\
\hline 3 & Etc. & $\ldots$ & $\ldots$ & $\ldots$ \\
\hline & Opportunity Total Score & & & $\ldots$ \\
\hline & THREAT & & & \\
\hline & & & \\
\hline
\end{tabular}


Swot Analysis in the Planning of Software Product Marketing Strategy to Cope With ....

\begin{tabular}{|l|l|l|l|l|}
\hline 1 & Economy Environment & 0,05 & 4 & 0,2 \\
\hline 2 & $\begin{array}{l}\text { Competition the Quality Product and Service } \\
\text { Competitors }\end{array}$ & 0,1 & 3 & 0,3 \\
\hline 3 & Etc. & $\ldots$ & $\ldots$ & $\ldots$ \\
\hline & Threat Total Score & & $\ldots$ \\
\hline
\end{tabular}

Source: Adapted from Rangkuti (2016: 26)

\section{SWOT Matrix}

Rangkuti (2016) the tools used to compile the company's strategic factors is SWOT Matrix. This matrix can clearly describe how the external opportunities and threats faced by the company can be adjusted to the strengths and weaknesses possessed by the company. This matrix can produce four sets of strategic alternatives possibilities.

a. SO Strategy

This strategy is based on the company's way of thinking, namely by exploit all strength to seize and utilize opportunities as maximum as possible.

b. ST Strategy

This is a strategy in using the strength of the company to overcome the threat.

c. WO Strategy

This strategy is applied based on the utilization of existing opportunities by minimizing the existing weaknesses.

d. WT Strategy

This strategy is based on defensive activities and seeks to minimize the existing weaknesses and also avoid threats.

Data Validity

Moeloeng (2013:324) stated that to establish the data validity required the examination techniques. Implementation of examination techniques based on certain criteria. There are four criteria used namely credibility, transferability, dependability and confirmability.

\section{Research subject}

Sources of primary data in this study is used to obtain accurate data because the data source from direct information. In this research, there are two sources of data:

1. The key information (key informant) in the form of General Manager of PT. PATT namely Mister Widhy Dwi Mahardika whose considered important and understand the required information in this study

2. Supporting Informant in this research namely R\&D MCF as the Business Incubator, business partners, and employees of PT.PATT

\section{Findings And Discussion}

Diversification strategies for the development of new products and a new segment was conducted by PT.PATT with pursuing a strategy of marketingPartner relationship Management, Product Development, and Market Penetration. As for the explanation was obtained from the following interviews result

\section{Partner Relationship Management}

Partner Relationship Management which conducted by the company was cooperating with distributor and radio stations to market the products. For marketing we also had collaborated with several companies for social media marketing, for event marketing we also had cooperated with the radios to publish our product, specific products that sold massively.9/16/2016Besides that collaboration conducted with several companies and educational institutions for product development. The following is the narrative of General Manager of PT. PATT:Often we collaborate, in terms of infrastructure we also had IBM partner, SERVER infrastructure we partner with IBM. Our solutions support supported by IBM for hardware, servers and so on. For knowledge resource, we partner with several universities in Malang, which is fresh, young, and a lot of innovation.9/16/2016

\section{Product Development}

Product Development which conducted by the company leads to creative industry with creating games applications and hologram. The following is the narrative of General Manager of PT. PATT: Then the computer can also be used to display, animations display that implemented in hologram like this. It also can support the business .... and next the animation for mapping projector can also be used. Games also one of the sectors in IT which collaborate between IT with art, create a character, create the gameplay, create the role play. That widely developed in education game.9/16/2016 


\section{Market Penetration}

Market Penetration which is conducted by the company is done by creating a website specifically for SMEs. This website is made with special prices and services. The following is the several narratives of General Manager of PT. PATT:For SMEs usually budgeting for IT-based services typically small. We provide instant website service specifically for SMEs, This newly we try. So that instant website development website services for SMEs, This newly we try.

From the price exactly. The price and services also.... services can be reused for others SMEs. So the making of this software we could someday be applied to other SMEs.

The price is cheaper because of mass...9/16/2016

\section{Discussion}

SWOT analysis using SWOT Matrix method in which there are calculation using EFAS Matrix and IFAS Matrix. The following are the points of strength, weakness in the IFAS calculation table, and opportunity, Threat in the EFAS table.

Table 4: Result of EFAS Calculation

\begin{tabular}{|l|l|l|l|l|}
\hline EFAS (External Strategic Factors Analysis Summary) & Score & Worth & Rating & Score(worth x Rating) \\
\hline No & The Factors of External Strategy & & & \\
\hline & OPPORTUNITY & 0,05 & 3 & 0,15 \\
\hline 1 & Creative Economy Industry Environment & 0,05 & 3 & 0,15 \\
\hline 2 & Segment Product Development Opportunities & 0,1 & 3 & 0,3 \\
\hline 3 & Business Incubator & 0,1 & 2 & 0,2 \\
\hline 4 & The Difference in the Segment in competition with competitors & & 0,8 \\
\hline & Opportunity Total Score & & & \\
\hline & & & & \\
\hline & THREAT & 0,05 & 4 & 0,2 \\
\hline 1 & Economy Environment & 0,1 & 3 & 0,3 \\
\hline 2 & Competition the Quality Product and Service Competitors & 0,05 & 3 \\
\hline 3 & the paradigm of society is not good about the software product & 0,4 & 0,15 \\
\hline 4 & the difference in price by competitors & 0,1 & 0,4 \\
\hline 5 & Dynamic Market Condition & 2 & 0,2 \\
\hline & Threat Total Score & & 1,25 \\
\hline
\end{tabular}

Table 5: Result of IFAS Calculation

\begin{tabular}{|c|c|c|c|c|}
\hline \multicolumn{2}{|c|}{ IFAS (External Strategic Factors Analysis Summary) } & \multicolumn{3}{|l|}{ Score } \\
\hline No & The Factors of Internal Strategic & Worth & Rating & Score(Worth x Rating) \\
\hline & STRENGTH & & & \\
\hline 1 & The Availability of Online Marketing & 0,1 & 4 & 0,4 \\
\hline 2 & The Existence of Internal Links & 0,3 & 4 & 1,2 \\
\hline 3 & Vast Knowledge by Marketing Team & 0,1 & 3 & 0,3 \\
\hline 4 & An Experienced Team of Developers & 0,02 & 3 & 0,06 \\
\hline 5 & Collaboration with Several Distributors in Marketing & 0,05 & 2 & 0,1 \\
\hline 6 & $\begin{array}{l}\text { Collaboration with Several Vendors in The Development of } \\
\text { Infrastructure and Products }\end{array}$ & 0,01 & 1 & 0,01 \\
\hline 7 & Product Customize & 0,1 & 4 & 0,4 \\
\hline \multirow[t]{3}{*}{8} & Experienced with Some Clients & 0,01 & 3 & 0,03 \\
\hline & Strength Total Score & & & 2,5 \\
\hline & WEAKNESS & & & \\
\hline 1 & Human Resource Development & 0,1 & 3 & 0,3 \\
\hline 2 & Take Time in The Product Segment Expansion & 0,1 & 4 & 0,4 \\
\hline 3 & High Price Product for Company Segment & 0,04 & 4 & 0,16 \\
\hline 4 & Ordering Quantity of Products that Have not been Regularly & 0,05 & 2 & 0,1 \\
\hline \multirow[t]{2}{*}{5} & take time to improve the quality of services & 0,02 & 3 & 0,06 \\
\hline & Weakness Total Score & & & 1,02 \\
\hline
\end{tabular}

Results from IFAS Table shows that Strengths Factor obtained a score of 2,5 and weakness obtained a score of 1,02. The differences obtained between strength and weakness is 1,48. In EFAS table the Opportunity obtained a score of 0,8 and threats obtained a score of 1,25. The differences obtained between Opportunity and threats is 0,45 . 


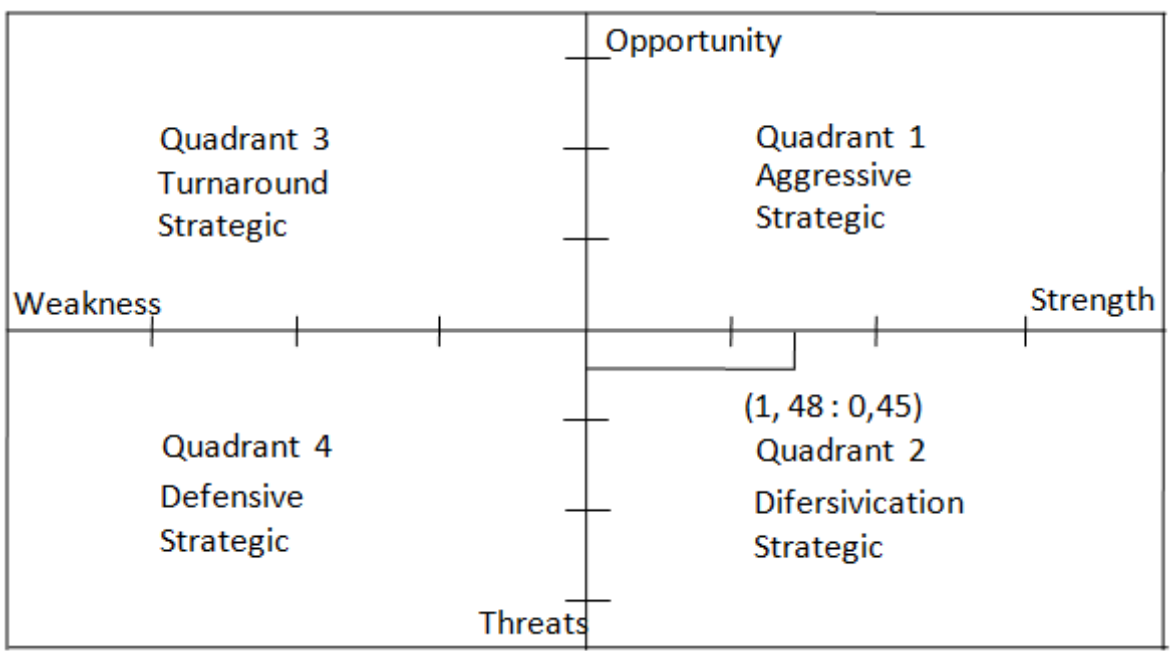

Figure 2: Result of SWOT analysis of PT. PATT

The results of SWOT analysis table determine the strategies used is in quadrant 2 namely facing external threats with internal strength of the company. The strategy used is diversification. Diversification is the company's growth strategy through expansion of product diversity and market from the target segment all this time. This is in accordance with current condition of the company, in which the company will expanding the segment and product.

Creative economy as an external factor that affecting the company's internal conditions create increasingly dynamic conditions. By producing 16 sectors and the opportunity to collaborate produce a wide range of solutions become the company concerns to moved searching for a new segment outside the previous segment. In one of strategy to improve local creative entrepreneurs that is competitive and dynamic, the strategy conducted is to facilitate and develop the business incubators which involves all stakeholders and managed professionally (Pangestu 2015: 305). Business Incubator also became a meeting place for practitioners, in which they exchange information and knowledge. Cantu (2015) The role transformation from incubator highlighting their role as science mediator which supports the incorporation of a wide range of science with external actor who had meso and macro network. Business incubator is a company external opportunities. With the existence of business incubator the opportunity to collaborate with a wide range of sectors to create innovative products can be conducted. Marketing strategy in utilizing these opportunities there were three, namely partner relationship management, product development, andmarket penetration.

Partner Relationship Management is partnering with other companies in order to increase the value of a product to be offered to the customer. This is conducted to make the product innovation in order to deliver a better value to the customer. In addition with Partnership the solutions to solve the problems in the external environment becomes easier, because each individual who collaborate shared the risks from each job. Information for the opportunity to obtain market also become greater with partnership. Accoding to Paggiaro and Andrea, (2014) the company's growth and market presence strengthened by generating an opportunity to build new relationships or expanding existing relationships. In addition, partnership opportunities with business incubators gives a large impact. Joseph, 2009; Allen and Levine, 1986; Roper, 1999 in Busler, Hanadi, and Ali (2015) business incubator acts as an economic strategy for building the update of emergence of social and economic opportunities in the growth and commercial of new product, new processes and new business models. Advantages of strategy and objective led to several elements, such as creativity, innovation and entrepreneurship in connection with business incubation models.

From the research findings found out that PT. PATT already made several partnerships with several distributors, universities and some practitioners. Partnership with distributor is focused for marketing. Distributor company for social media marketing and with radio station for event marketing. Partnership with educational institutions such as universities conducted by the company for product research development. Beside that PT.PATT also conducting collaboration with some practitioners in the field of animation, and the resulting product is a hologram and a projector. Partner Relationship Managementconducted because influenced by company external conditions which have penetrated to the creative industry, and industrial segment is a segment which has not been tried by PT. PATT. In order to survive and be able to face the competition, the company collaborate or conduct the strategy of partner relationship management with several resource external.

Product innovation is also a strategy called Product development. In facing the Creative Economy Era, product development is one of the strategies that can be conducted by PT. PATT collaborated with business 
incubator. There are several things the cause of product development conducted the first is creative economy which form the creative industry and second is expansion of company's product categories from the previous product types. Before creative economic PT. PATT only focusing on software-management science based- such as Repress for attendance and employee payroll and CANVASSER for sales monitoring.

In the process of Product Development also needed innovation. Enshun Jr (2009) innovation as the implementation of the ideas which result in improved products or services that create value, promote the competitive advantages, and produce a favorable outcome. In some products such as hologram projector, PT. PATT already collaborated with practitioners in the animation sector. Hologram can also help a business process because the looks in the form of display so that suitable for marketing a product from clients. With an eye-catching holographic display makes product presentation more attractive. Paggiaro and Andrea, (2014) entrepreneurial companies are motivated primarily by the pursuit of new opportunities and not by the resources they control today. Growth opportunities can arise from a variety of sources: new products or new processes, new ways to deliver services to customers, and so on. From the finding results, PT. PATT was headed for the creative industry with the planning will create a games product. Games product is a collaboration of IT and art. This product is specified for the creative segment. Besides games, the company is following the trend of the games products in the form of VR (Virtual Reality). VR is a game that can interact with the environment in the form of simulation.

Strategy of Market Penetration which also conducted by PT. PATT. The company already has several products, already marketed and had market segment. Some of these products are HRExpress an application of payroll and attendance system based, CANVASSER application of sales monitoring / sales which can be installed using Android, SERVER procurement, CCTV camera for monitoring, and Wall Display. Proven with the company already has several clients in the government such as Police and some private companies. But the segment that became the initial target of PT. PATT has a dominant macro factors. Government and private companies certainly have the economic background which is very supportive in the development of infrastructure for their company. This is contrast with the other segments that have the economic background which is not as strong as government and private companies. For example, school, hotel, restaurant and SMEs are the segments that also require technology as a solution of their work.

According to Caragher, Carroll, Garver, LoDuca in O'Neil and Douglas (2012) in their article entitled "Craft Beer: penetrating a niche market", all the literature reviewed shows that businesses, that demonstrate a commitment to a niche market by superior offering and knowledge gain differentiation and dominance in a niche market. Furthermore, literature strongly indicates that satisfy consumer needs in niche segments positively correlated with the consumer identification with the victims and providers, and is a key determinant of customer satisfaction in a niche market (Garver, Zhu in O'Neil and Douglas 2012). In research finding, PT. PATT is trying the product website designed specifically for the SME segment. This product has a service and special price. In addition, for existing products such as Repress, canvasser, website construction, procurement of servers the company further enhance the quality of services such as aftersales and technical support

\section{Conclusion}

In this study SWOT analysis is in quadrant II, which means that the appropriate strategy for the company of PT. PATT based on an analysis of factors of Strength, weakness, Opportunity, and Threat is Diversification strategy. Diversification is a strategy for the establishment of new products for new markets. The new segment that will be faced is the Era of Creative Economy in Indonesia. Creative Economy Era focuses on several sectors in the field of art. In Malang city itself there are 16 sectors in the field of art. To manage the variety of creative industry sector in several cities in Java to Bali establish a business incubator. Business incubator as a place to exchange information, share knowledge, technology development and matching between buyers and sellers.

Creative Economy Era is the external conditions that will be faced and an opportunity to collaborate. In conducting the diversification strategy to face the Creative Economy Era PT. PATT perform some marketing strategies, among others are partner relationship management, product development, and market penetration. In this research PT. PATT already conducting those strategies and there is some planning ahead about some of the new products for new segments. Company Partner relationship Management already collaborated with several other companies in conducting social media marketing and radio station for event marketing. For Product Development several planning ahead PT. PATT will conduct collaboration with educational institutions such as universities to perform product development research. Planning ahead PT. PATT will create the products of games application in which collaboration between IT and the arts. Market Penetration to several existing products, namely HRExpress, CANVASSER, SERVER procurement will be improved in terms of its service. For Website will be created specifically for the SME segment with customized service and cheaper prices. This strategy is used to compete with competitors and the trend of the creative economy. 


\section{Further Research}

The results indicate that IT technology has a lot of product development and segments that can be produced. Through the collaboration will be a lot of innovation product created. The first thing to do is to observe and specify the target market that will be faced. Dynamic external environmental factor will greatly affect the development of IT technology. The second thing to do is how an IT technology company can properly regulate their internal conditions such as human resource and knowledge in the development of a product. Human resource and knowledge is highly influential in providing convenience in the product development process. For further research, researchers should be careful in choosing external factors that influenced the company either for the development of the segment and revenue. Then the researchers must also careful in observing influential internal conditions such as human resource and several other internal factors.

In the final results proves that the planning of software product marketing strategy can be conducted using SWOT analysis. The development of this research can be expanded through analysis of internal and external conditions, and marketing strategies that will be used in addition to those mentioned in this study. Hopefully, through this study could encourage other researchers to use a SWOT analysis for planning on the software product.

\section{References}

[1] Al-Mubaraki, Hanadi., Beverlee B. Anderson. 2012. The Gateway Innovation Center: Exploring Key Element of Developing a Business Incubator. State of Kuwait. Kuwait University, Kuwait City

[2] Akarte, Miling M., Sanjaykumar R. Gangurde. 2015. Segmentation Based Product design Using Preferred Features. Benchmarking: An International Journal. India. National Institute of Industrial Engineering, Mumbai

[3] Athanasios, VaiaTsitsipatiChirstodoulou. 2014. SWOT Analysis of the Truffles Market in Greece. Greece. Department of Forest economic, Faculty of Forestry and natural Environment, Aristotle University of Thessaloniki

[4] Brooksbank, Roger. 1999. The Theory and Practice of Marketing Planning in The Smaller Business. Marketing Intelligence \& Planning. New Zealand. University of Waikato

[5] Busler, Hanadi Mubarak Al - Mubaraki Michael. 2010. Business Incubator Models of the USA and UK: A SWOT analysis. USA. Richard Stockton College.

[6] Busler, Michael., Hanadi Mubarak Al-Mubaraki., Ali Husein Muhammad. 2015. Categories of Incubator Success: A Case Study of Three New York Incubator Programmes. World Journal of Science, Technology and Sustainable Development. USA. School of Business, Richard Stockton College.

[7] Cantu, Chiara. 2015. A Service Incubator Business Model: External Networking Orientation. IMP Journal. Italy. CAttolica University

[8] Enshun Jr, Joseph P. 2009. Business Incubation as Strategy. Business Strategy Series. USA. Department of Business Management

[9] Estelami, Hooman and Heather Bergstein. 2002. A Survey of Emerging Technology for Pricing New - to - The World Product. Journal of Product \& Brand Management. USA. Graduate School of Business, Fodham University, New York, NY.

[10] Gruber, Thorsten., Alexander E. Reppel dan Isabelle Szmigin. 2006. The Ipod Phenomenon: Identifying a Market Leader's Secrets Through Qualitative Marketing Research. Journal of Product \& Brand Management.UK. Birmingham Business School, The University of Birmingham, Edgbaston

[11] Kotler \& Armstrong. 2009. Marketing An Introduction. Ninth Edition. New Jersey: Prentice Hall.

[12] Mariscal, Judith. 2009. Market structure and penetration in the Latin American mobile sector. Mexico. Centro de Investigación y Docencia Económica (CIDE), Carretera Me'xico-Toluca. Vol. 11 Iss 2 pp. 24 - 41

[13] Minola, Tommaso., Lucio Cassia. 2012. Hyper-Growth of SMEs Toward a Reconciliation of Entrepreneurial Orientation and Strategic Resource. International Journal of Entrepreneurial Behavior \& Research. Italy. Department of Economic and Technology Management and CYFE - Center for Young and Family Enterprise, University of Bergamo.

[14] Mitrega, Maciej. 2012. Network Partner Knowledge and internal Relationship Quality and Company Performance. Poland. University of Economic in Katowice

[15] Moleong. 2013. MetodologPenelitianKualitatif.Bandung: PT RemajaRosdakarya Offset.

[16] Paggiaro, Andriano., Andrea Furlan and Roberto Grandinetti. 2014. Unveiling The Growth Process:Entrepreneurial Growth and The Use of External Resources. International Journal of Entrepreneurial Behavior\& Research. Italy. Department of Statistic, University of Padova

[17] O’Neil, Martin and Douglas W. Murray. 2012. Craft Beer: Penetrating a Niche Market. British Food Journal. USA. College of Human Sciences, Auburn University, Auburn, Alabama.

[18] Pearce, John and Richard B. Robinson. 2008. Manajemen Strategis : Formulasi, Implementasi, dan pengendalian. Jakarta: Salemba Empat

[19] Pangestu, DR. Mari Elka. 2008. Pengembangan Industri Kreatif Menuju Visi Ekonomi Kreatif Indonesia 2025. Jakarta. Departemen Perdagangan RI

[20] Rangkuti, Freddy. 2016. Teknik Membedah Kasus Bisnis Analisis SWOT Cara Perhitungan Bobot, Rating, dan OCAI. Jakarta: PT. Gramedia.

[21] Toor, Tanjider. 2014. Market Segmentation for Penetrating Deeper into The Contact Lens Market. Strategic Direction. Canada. IBM, Markham Ontario.

[22] Is SWOT analysis Still Fit for Purpose? The Management Tool has been Exploring Strengths, Weakness, Opportunity and Threats for Decade. Strategic Direction, Vol. 31 Issue 4 pp. 13 - 15., 2015. Retrieved from http:/ /www. emeraldinsight. com/doi/pdfplus/10.1108/SD-02-2015-0024

[23] Wang, Tieshan., Yongtao Song, Qin Su dan Qiang Liu. 2012. Impact of Business Relationship Function on Relationship Quality and Buyer's Performance. Journal of Business \& Industrial Marketing. China. School of Economics and Finance, Xi'an Jiatong University, Xi'an 